\title{
Protective Effect of Obestatin on Testicular Ischemia/Reperfusion Injury in Rats
}

\author{
NADINE A. RAAFAT, M.D.; SUZAN M.M. MOURSI, M.D. and WESSAM M.R. ASHOUR, M.D. \\ The Department of Physiology, Faculty of Medicine, Zagazig University
}

\begin{abstract}
Background: Testicular torsion (the most common cause of testicular ischemia) is one of the urologic emergencies occurring frequently in neonatal and adolescent period. Although reperfusion of the testis is the key treatment after ischemia, it enhanced the formation of reactive oxygen species (ROS) that result in testicular damage and cell apoptosis. The effect of obestatin on testicular ischemia-reperfusion injury has not been evaluated previously.
\end{abstract}

Aim of Study: This study was delineated to investigate the potential protective effect of obestatin on testicular ischemia/reperfusion ( $\mathrm{I} / \mathrm{R})$ injury in rats.

Material and Methods: 30 healthy adult male albino rats weighting 194-217g were involved and divided into 3 equal groups, group (I): Sham operated control group, group (II): Testicular ischemia reperfusion (I/R) group and group (III): Obestatin treated ischemia reperfusion (I/R-obestatin) group; received obestatin $(100 \mathrm{~g} / \mathrm{gg})$ intravenously $15 \mathrm{~min}$ before the testicular detorsion (reperfusion). Serum testosterone level was measured and orchiectomy was performed 6 hours after testicular detorsion and examined histopathologically and immunohistochemically for evaluation of pro-apoptotic Bax and anti-apoptotic Bcl-2 proteins expression. Testicular malondialdehyde (MDA), interleukin-1 $\beta$ (IL-1 $\beta$ ) and tumor necrosis factor- $\alpha$ (TNF- $\alpha$ ) levels and superoxide dismutase (SOD), catalase (CAT), glutathione peroxidase (GPX), caspase8 and caspase- 3 activities were also evaluated.

Results: This study demonstrated that administration of obestatin prior to detorsion significantly increased the reduced serum testosterone level and attenuated the testicular tissue damage observed in I/R group. It also reversed the increased MDA, TNF- $\alpha$ and IL- $1 \beta$ levels and significantly enhanced the antioxidant enzymes activities in the ipsilateral I/R testis. Moreover, it improved the significant high levels of caspase8 and caspase- 3 and alleviated the increased Bax and the reduced Bcl-2 proteins expressions noticed in I/R testis.

Conclusion: Obestatin has a protective effect against testicular I/R injury which can be attributed to its anti-oxidant, anti-inflammatory and anti-apoptotic properties.

Key Words: Obestatin - Reperfusion injury - Testis - Oxidative stress.

Correspondence to: Dr. Nadine A. Raafat,

E-Mail: nadraf@yahoo.com

\section{Introduction}

TESTICULAR torsion is one of the emergency conditions which requires immediate surgery to reperfuse the affected testis, however, attempt to reperfuse ischemic tissue may cause further damage to the testis. Many studies reported a loss of germ cells and disruption of the seminiferous epithelium after ischemia reperfusion (I/R) injury of the testis $[1,2]$.

Overgeneration ROS is thought to play a critical role in I/R injury [3]. Toxic free oxygen radicals, such as nitric oxide $\left(\mathrm{NO}^{-}\right)$, superoxide anions $\left(\mathrm{O}_{2}{ }^{-}\right)$, hydrogen peroxide $\left(\mathrm{H}_{2} \mathrm{O} 2\right)$, and hydroxyl radicals $\left(\mathrm{OH}^{-}\right)$can lead to lipid peroxidation, protein denaturation, DNA damage and apoptosis [4]. Testes, also, are more sensitive to free radical damage due to their high content of polyunsaturated fatty acids [5].

Moreover, Shih et al., [6] demonstrated the role of cytokines and infiltration of activated polymorphonuclear leukocytes in ischemia reperfusion injury in rats. The release of cytokines such as IL$1 \beta$ and TNF- $\alpha$ after reperfusion results in recruitment of neutrophils and macrophages, causing germ cell apoptosis, disruption of spermatogenesis and testicular atrophy [7].

In addition, as a consequence of testicular I/Rinduced ROS generation, the caspase-dependent apoptosis pathways are activated leading to germ cell death. High levels of the initiator caspase- 8 and the executioner caspase- 3 were increased during testicular I/R [8].

On the other hand, information from the literature indicates that antioxidant and antiinflammatory treatment is inevitable before and after surgical intervention in I/R injury [9]. Obestatin is a circulating 23 -amino-acid peptide hormone, encoded by the same gene as ghrelin and predom- 
inantly produced in the stomach [10]. Apart from the stomach, obestatin expression was also found in other tissues, such as the endocrine pancreas, adipose tissue, liver, skeletal muscle and the male reproductive system [11].

Moreover, it has been demonstrated that obestatin can attenuate ischemia-reperfusion injury in other tissues subjected to $\mathrm{I} / \mathrm{R}$ insults via reducing oxidative stress and inflammatory process and improving antioxidant activity [12,13]. However, to our knowledge, no studies have examined the effect of obestatin on testicular ischemiareperfusion injury.

So, this study was designed to investigate whether obestatin can protect the testis from ischemia-reperfusion injury in rats. In an attempt to elaborate the mechanisms of the potential protective effects of obestatin, we investigated its effect on the redox status of the testes by assessing the levels of lipid peroxides and antioxidant enzyme activities in testes. We also assessed its probable anti-inflammatory and anti-apoptotic effects through estimation of some testicular inflammatory and apoptotic markers.

\section{Material and Methods}

The present study was carried out in Faculty of Medicine, Zagazig University, in the period from February to June 2019 and involved 30 healthy adult male albino rats weighing 194-217g (derived from the experimental animal services house of Faculty of Pharmacy). Rats were kept for 1 week for habituation in clean standard cages in groups of five. They received food and water ad libitum and housed at room temperature and in a $12 \mathrm{~h}$ light/dark cycle. The experimental protocol was approved by the Institutional Research Board (IRB) and the ethics committee of Faculty of Medicine, Zagazig University.

Rats were equally divided into three groups: Group (I): Control group, rats in this group underwent sham operation without torsion and received 1 Ml Normal Saline Intravenously, Group (II): The ischemia/reperfusion (I/R) injury group which underwent 2 hours of testicular torsion (ischemia) followed by 6 hours of detorsion (reperfusion) and received $1 \mathrm{ml}$ normal saline intravenously $15 \mathrm{~min}$ before detorsion, and group (III): Obestatin treated I/R injury group (I/R-obestatin) which received obestatin (lyophilized powder form Sigma Aldrich Co.-USA) at a dose of $100 \mathrm{~g} / \mathrm{kg}$ intravenously 15 min before the testicular detorsion [12]

Surgical ischemia reperfusion (torsion / detorsion): Rats were anesthetized by intraperitoneal administration of $2 \%$ sodium phenobarbital $(50 \mathrm{mg} /$ $\mathrm{kg}$ ). The skin of scrotal area was shaved and then prepared with $10 \%$ povidone iodine solution. A right-sided mild scrotal vertical incision was performed to access the testis. Torsion was created by twisting the right testis $720^{\circ}$ in a counterclockwise direction and maintained by fixing it to skin of scrotum with a $4 / 0$ silk suture. The testis was detorsioned to the natural position after 2 hours of torsion, and the scrotal skin was closed with 4/0 silk. During sham operation, the testis was localized through a right-sided scrotal incision, and then the incision was sutured with $4 / 0$ silk without additional intervention [2].

Sample collection: After 6 hours of detorsion, blood samples were collected from the orbital sinus and serum was separated by blood centrifugation at $3000 \mathrm{rpm}$ for 15 minutes and kept at $20^{\circ} \mathrm{c}$ until measurement of serum free testosterone level. After blood sampling, laparotomy was done after sacrificing the rats by cervical dislocation under mild ether anesthesia. The right testis of each rat was removed and divided into two halves, with one half fixed in Bouin's fixative for 24 hours for histopathological and immunohistochemical examination, and the other half immediately frozen at $-80^{\circ} \mathrm{C}$ then homogenated for biochemical analysis of malondialdehyde (MDA), tumor necrosis factor$\alpha$ (TNF- $\alpha$ ) and interleukin $1 \beta$ (IL-1 $\beta$ ) levels and superoxide dismutase (SOD), glutathione peroxidase (GPX), catalase (CAT), caspases- 8 and -3 activities [2].

Preparation of testis homogenate: The testes halves were sliced into small pieces, and then homogenized in $1 \mathrm{ml}$ physiological saline. The homogenates were centrifuged at 20,000g-force for $30 \mathrm{~min}$ at $4{ }^{\circ} \mathrm{C}$. The supernatants were collected and stored at $20^{\circ} \mathrm{C}$ until later analysis [14].

\section{Serum free testostosterone level:}

Serum free testostosterone level was measured using testosterone ELISA kit (BioCheck, Dr. Foster City, CA 94404) as described by Tietz, [15]

\section{Evaluation of testicular redox status:}

MDA level and SOD, CAT and GPX activities were measured using specific ELISA kits (Sigma Aldrich Co.-USA) according to Ohkawa et al. [16], Kakkar et al. [17], Luck [18] and Reddy et al. [19] respectively.

Measurement of testicular inflammatory biomarkers:

IL- $1 \beta$ and TNF- $\alpha$ concentrations were quantified according to the manufacturer's instructions 
and guidelines using ELISA kit (Bio diagnostic company, Egypt).

\section{Evaluation of apoptosis markers:}

Activities of caspases- 8 and -3 were measured using their specific colorimetric assays following their manufacturer's recommendations (Sigma Aldrich Co.-USA).

Histopathological examination:

Ipsilateral testes halves from all groups were fixed in Bouin's solution and followed by dehydration in a descending series of ethyl alcohol, then cleared in xylene and embedded in paraffin. Paraffin sections of testes were cut at $5 \mathrm{mon}$ a rotary microtome, mounted on slides and stained with hematoxylin eosin $(\mathrm{H} \& \mathrm{E})$ and examined under a light microscope equipped with a digital camera [20]

Immunohistochemical study:

Paraffin sections were deparaffinized in xylene and rehydrated using ascending grades of alcohol and used to evaluate the expression of Bax and $\mathrm{Bcl}-2$ proteins using monoclonal Bax and monoclonal Bcl-2 antibodies respectively (Sigma Aldrich Co.-USA) as described by Zhou et al., [21]

\section{Statistical analysis:}

Study results were represented as mean $\pm S D$. The Statistical Package for the Social Sciences
(SPSS), version 19.0 (SPSS Inc., Chicago, IL, United States) was used for performing the statistical analysis. Analysis of variance (ANOVA) followed by LSD post hoc test was performed to compare means of the different groups. $p$-values $<0.05$ were considered statistically significant.

\section{Results}

Testicular I/R resulted in histological changes in terms of disruptions of spermatogonia throughout the lumen of seminiferous tubules with spermatogenic arrest and expansion of interstitial tissue (Fig. 1B). However, treatment with obestatin resulted in a remarkable improvement in the structural and cellular morphology of the seminiferous tubules and interstitial spaces (Fig. 1C).

Serum free testosterone level was also decreased in I/R group compared to control, but this effect was improved by obestatin $(p<0.001)$. In addition, it was observed that MDA, IL- $1 \beta$ and TNF- $\alpha$ testicular levels, caspase 3 and 8 activities $(p<0.001)$ and Bax protein expression were increased, while SOD, CAT and GPX activities $(p<0.001)$ and $\mathrm{Bcl}-2$ expression were decreased in I/R group. These effects were reversed by obestatin in I/R-obestatin group $(p<0.001)$ (Table 1 and Figs. $2 \& 3 \mathrm{~A}-\mathrm{C})$.

Table (1): Serum free testosterone level and testicular TNF- $\alpha$, IL-1 $\beta$, MDA, SOD, CAT, GPX, caspase-8 and caspase- 3 in all studied groups.

\begin{tabular}{|c|c|c|c|}
\hline Parameters & Group I & Group II & Group III \\
\hline $\begin{array}{l}\text { Serum free testosterone }(\mathrm{ng} / \mathrm{ml}) \text { : } \\
\quad \mathrm{X} \pm \mathrm{SD} \\
p \text {-value of LSD }\end{array}$ & $4.82 \pm 0.40$ & $\begin{array}{l}1.02 \pm 0.17 \\
p<0.001 \mathbf{a}\end{array}$ & $\begin{array}{c}3.13 \pm 0.49 \\
p<0.001 \mathbf{a}, \mathbf{b}\end{array}$ \\
\hline $\begin{array}{l}T N F \alpha(p g / m g \text { protein }): \\
\mathrm{X} \pm \mathrm{SD} \\
p \text {-value of LSD }\end{array}$ & $32.01 \pm 3.23$ & $\begin{array}{l}66.38 \pm 8.24 \\
p<0.001 \mathbf{a}\end{array}$ & $\begin{array}{l}42.51 \pm 3.35 \\
p<0.001 \mathbf{a}, \mathbf{b}\end{array}$ \\
\hline $\begin{array}{l}I L-1 \beta(p g / m g \text { protein }): \\
\quad \mathrm{X} \pm \mathrm{SD} \\
p \text {-value of LSD }\end{array}$ & $34.33 \pm 3.47$ & $\begin{array}{l}57.3 \pm 4.74 \\
p<0.001^{\mathbf{a}}\end{array}$ & $\begin{array}{l}39.80 \pm 3.77 \\
p<0.01^{\mathbf{a}}{ }_{, p}<0.001 \mathbf{b}\end{array}$ \\
\hline $\begin{array}{l}\text { MDA (nmol/mg protein): } \\
\mathrm{X} \pm \mathrm{SD} \\
p \text {-value of LSD }\end{array}$ & $112.37 \pm 6.26$ & $\begin{array}{l}198.26 \pm 16.93 \\
p<0.001 \text { a }\end{array}$ & $\begin{array}{l}133.91 \pm 7.19 \\
p<0.001 \mathbf{a , b}\end{array}$ \\
\hline $\begin{array}{l}S O D(U / m g \text { protein }): \\
\mathrm{X} \pm \mathrm{SD} \\
p \text {-value of LSD }\end{array}$ & $72.58 \pm 7.55$ & $\begin{array}{l}34.85 \pm 5.27 \\
p<0.001 \mathbf{a}\end{array}$ & $\begin{array}{l}61.30 \pm 7.36 \\
p<0.01^{\mathbf{a}}{ }_{p}<0.001 \mathbf{b}\end{array}$ \\
\hline $\begin{array}{c}C A T \text { (U/mg protein): } \\
\mathrm{X} \pm \mathrm{SD} \\
p \text {-value of LSD }\end{array}$ & $16.98 \pm 2.36$ & $\begin{array}{l}7.28 \pm 1.62 \\
p<0.001^{\mathbf{a}}\end{array}$ & $\begin{array}{l}12.76 \pm 1.41 \\
p<0.001 \mathbf{a , b}\end{array}$ \\
\hline $\begin{array}{c}G P X(U / m g \text { protein }): \\
X \pm \mathrm{SD} \\
p \text {-value of LSD }\end{array}$ & $22.17 \pm 2.28$ & $\begin{array}{l}13.92 \pm 2.49 \\
p<0.001^{\mathbf{a}}\end{array}$ & $\begin{array}{l}18.99 \pm 1.27 \\
p<0.01^{\mathbf{a}}, p<0.001 \mathbf{b}\end{array}$ \\
\hline $\begin{array}{l}\text { Caspase- } 8(\mathrm{nmol} / \mathrm{min} / \mathrm{ml}): \\
\mathrm{X} \pm \mathrm{SD} \\
p \text {-value of LSD }\end{array}$ & $0.41 \pm 0.06$ & $\begin{array}{l}2.95 \pm 0.61 \\
p<0.001 \text { a }\end{array}$ & $\begin{array}{c}1.23 \pm 0.31 \\
p<0.001 \mathbf{a , b}\end{array}$ \\
\hline $\begin{array}{l}\text { Caspase }-3(\mathrm{~m} / / \mathrm{min} / \mathrm{ml}): \\
\mathrm{X} \pm \mathrm{SD} \\
p \text {-value of LSD }\end{array}$ & $9.18 \pm 0.90$ & $\begin{array}{l}16.17 \pm 1.62 \\
p<0.0011^{\mathbf{a}}\end{array}$ & $\begin{array}{r}11.93 \pm 0.83 \\
p<0.001 \mathbf{a}, \mathbf{b}\end{array}$ \\
\hline
\end{tabular}

$\mathbf{a}=$ Significant versus group I.

$\mathbf{b}=$ Significant versus group II. 

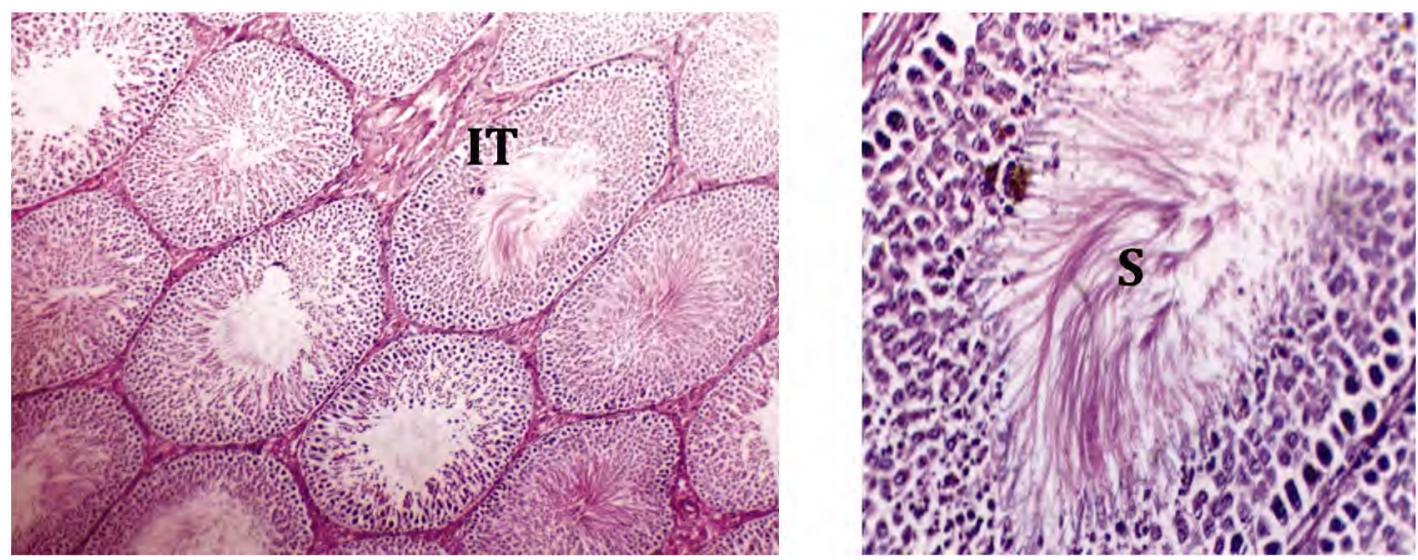

Fig. (1A): Testicular section from control group showing normal seminiferous tubules with normal spermatogenesis up to sperm formation (S) and normal interstitial tissue (IT) (H\&E staining, Magnification X10 inset X40).
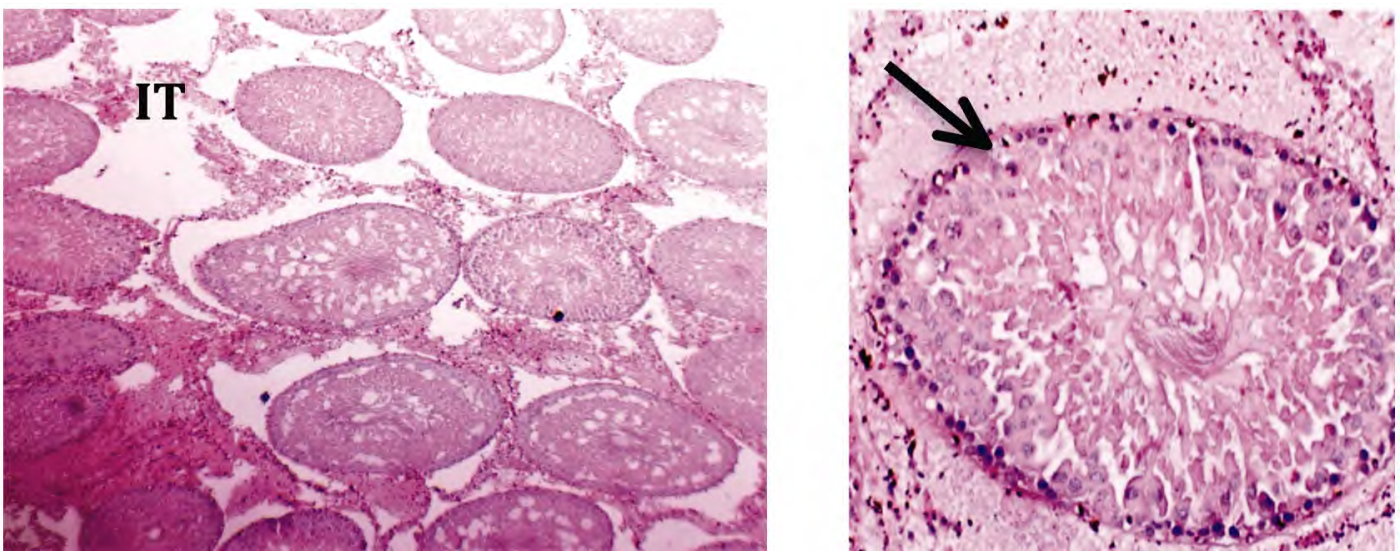

Fig. (1B): Testicular section from ischemia-reperfusion group showing disarrangement of spermatogonia throughout the lumen of seminiferous tubules with spermatogenic arrest (black arrow) and expansion of IT (H\&E staining, Magnification X10 inset X40).
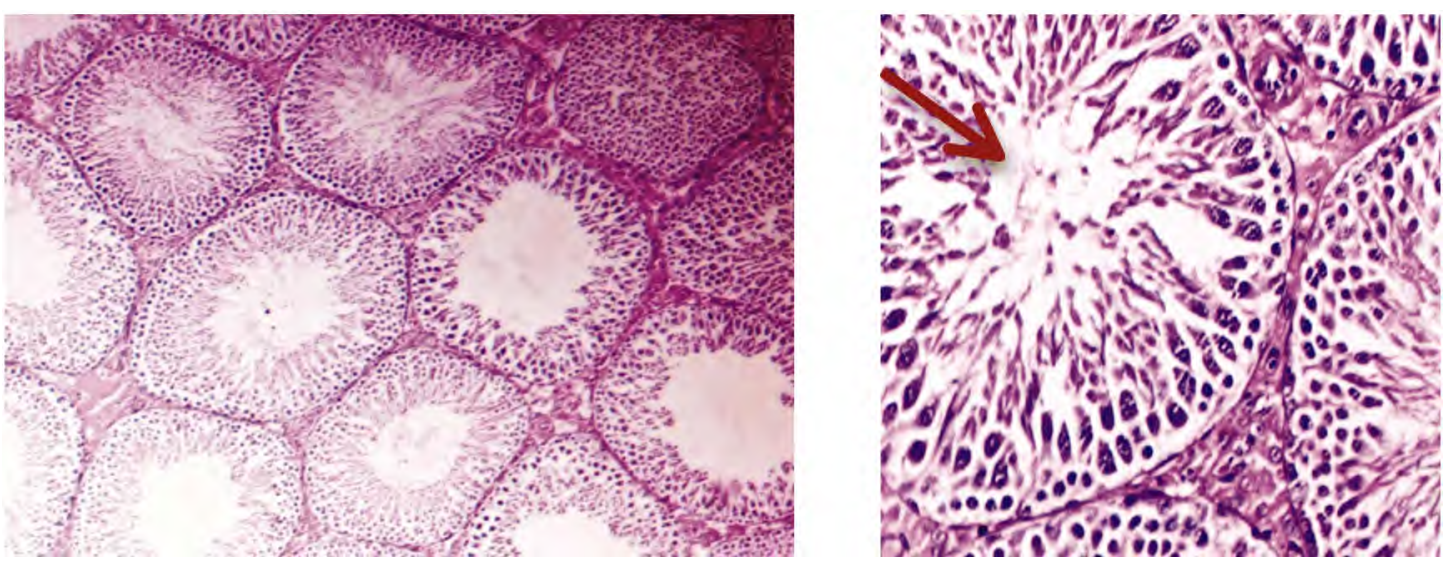

Fig. (1C): Testicular section from obestatin treated I/R group showing mild disruption of germ cell layers with recovery of spermatogenesis and spermatid formation (red arrow) (H\&E staining, Magnification $\mathrm{X} 10$ inset $\mathrm{X} 40)$. 


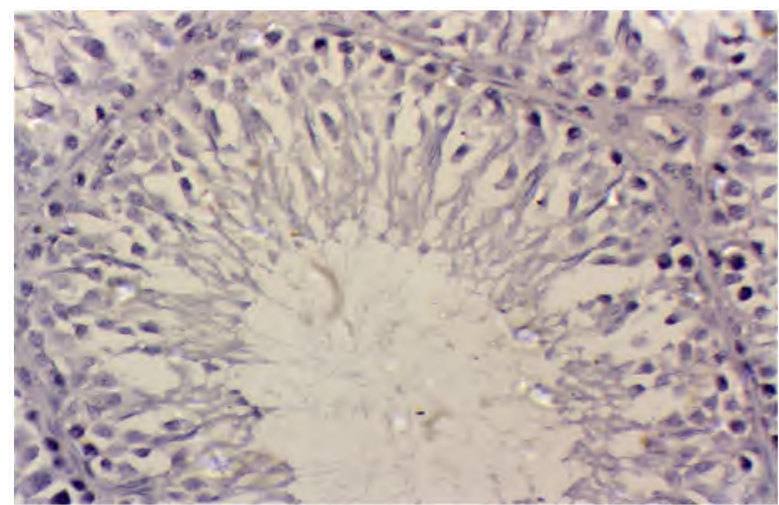

Fig. (2A): Testicular Bax immunohistochemistry from control group showing focal weak Bax expression in testicular control tissue (x400).

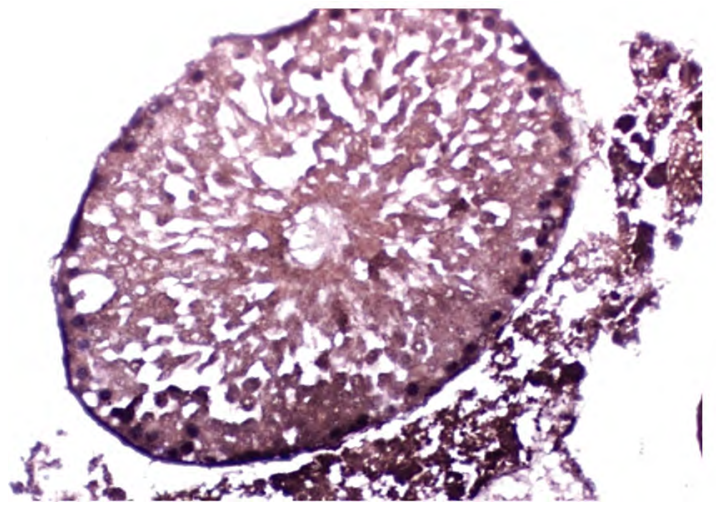

Fig. (2B): Testicular Bax immunohistochemistry from Ischemia reperfusion group showing marked Bax expression in testis exposed to I/R (x400).

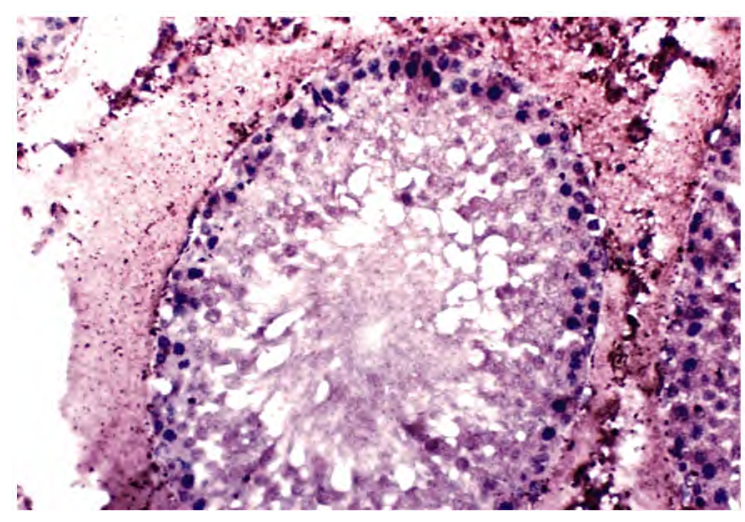

Fig. (2C): Testicular Bax immunohistochemistry from Obestatin treated I/R group showing decreased Bax expression in testicular tissue $(\mathrm{x} 400)$.

\section{Discussion}

Testicular torsion is one of the pediatric emergency conditions which require immediate surgical detorsion within 4-6 hours to avoid loss of testicular function [22]. Even if testicular torsion is corrected within this time period, testicular atrophy may develop subsequently [23]. The main cause of tissue

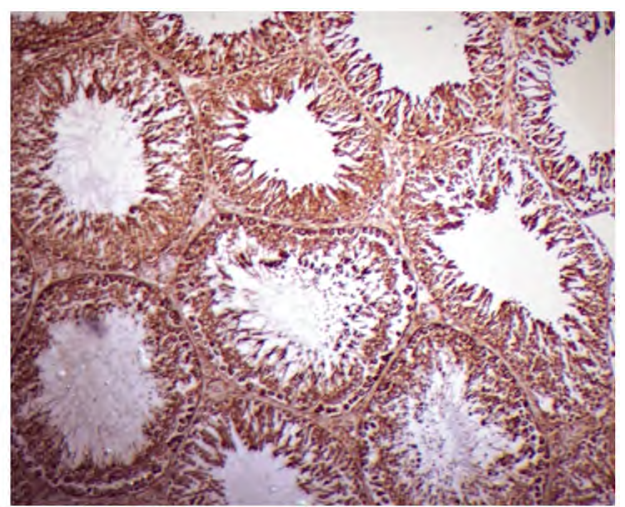

Fig. (3A): Testicular Bcl-2 immunohistochemistry from control group showing high $\mathrm{Bcl}-2$ expression in testicular tissue (x200).

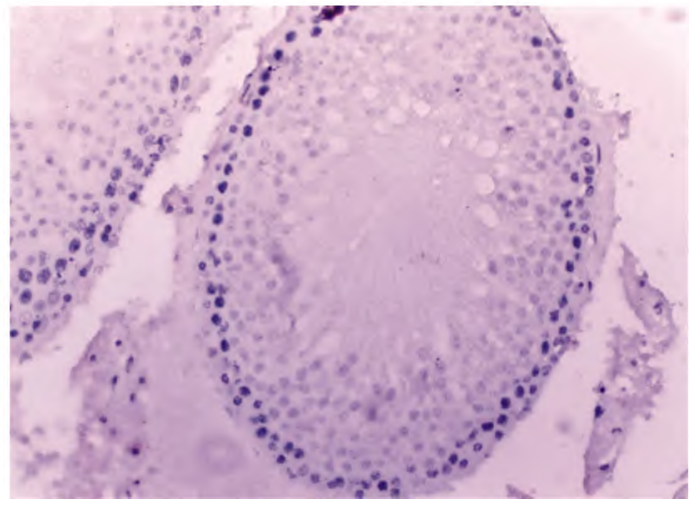

Fig. (3B): Testicular Bcl-2 immunohistochemistry from Ischemia reperfusion group showing absence of Bcl-2 in testis exposed to $\mathrm{I} / \mathrm{R}(\mathrm{x} 400)$.

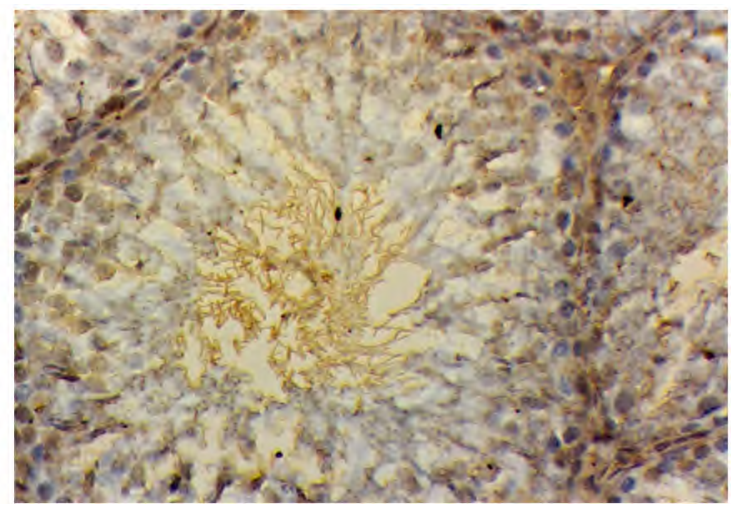

Fig. (3C): Testicular Bcl-2 immunohistochemistry from Obestatin treated $\mathrm{I} / \mathrm{R}$ group showing increased $\mathrm{Bcl}-2$ expression in testicular tissue $(\mathrm{x} 400)$.

injury after I/R is overproduction of ROS [24] Several enzymes and drugs that were intended to inhibit oxidative stress were used to treat testicular reperfusion injury [25]. Obestatin has been reported to protect against I/R injury in other tissues $[\mathbf{1 2 , 1 3 ]}$ Therefore, we attempted to use it for the treatment of testicular ischemia-reperfusion injury. 
In the present study, untreated rats that were subjected to 2 hours of ischemia (torsion) followed by reperfusion (detorsion) for 6 hours showed a significant testicular damage which led to decrease in serum testosterone level. These results are similar to that demonstrated by other studies $[2,26]$. However, it was noticed that administration of obestatin prior to detorsion significantly increased serum testosterone level and attenuated testicular tissue damage after testicular I/R.

During the ischemic phase of I/R process, hypoxia lead to reduced tissue ATP production, increased calcium influx into the intracellular compartment, elevating superoxide generator enzyme in addition to chemotactic factors stimulation with polymorphonuclear leukocytes migration to the ischemic region, which could generate superoxide radicals after reperfusion that aggravate tissue damage [27].

The decline in free testosterone level could be due to reduced Leydig cell function. I/R injury plays a role in Leydig cell dysfunction, either acting directly, causing germ cell apoptosis or indirectly by inducing oxidative stress [28]

Furthermore, the present study confirms that testicular I/R increases oxidative stress as shown by the significantly increased MDA level and the significantly decreased antioxidant enzymes activities (SOD, CAT and GPX) in I/R group. Ischemia causes an increase in intracellular hypoxanthine as a result of ATP breakdown and then, during reperfusion, xanthine oxidase converts hypoxanthine to uric acid plus large quantities of superoxide radicals in the presence of oxygen [29].

It is widely accepted that ROS has a significant role in the testicular ischemia-reperfusion injury [30]. During I/R, the antioxidant enzyme levels rapidly decrease and ROS is produced and begins to damage various cellular molecules, contributing to further pathological complications [31].

On the other hand, obestatin treatment reduced MDA level in the ipsilateral testis and significantly enhanced the antioxidant enzymes activities. In accordance with our results the protective effect of obestatin in I/R injury in other tissues such as liver [12] and heart [13] by its antioxidant activity has been demonstrated.

Moreover, our results demonstrated increased testicular TNF- $\alpha$ and IL- $1 \beta$ in I/R untreated group, whereas obestatin treated I/R group showed a significant decrease in their levels in comparison to untreated group. Similarly, it has also been shown that obestatin decreases the proinflammatory factors level in colonic mucosa in rats with colitis [11]. This effect may be explained by previous reports which demonstrated that obestatin reduced the expression of nuclear factor kappa-light-chain-enhancer of activated B cells $(\mathrm{NF}-\kappa \mathrm{B})$ in ischemia reperfusion [32]. NF- $\kappa \mathrm{B}$ is a crucial nuclear transcription factor for the regulation of TNF- $\alpha$, IL- $1 \beta$, and IL- 6 gene expression [33] .

ROS stimulate the release and the formation of various inflammatory mediators with powerful chemotactic effect [34]. Neutrophil recruitment is also an important source of ROS production. The increase in proinflammatory cytokines after I/R facilitates, transmigration of neutrophils from endothelium into the testis interstitium, ROS overproduction, cellular dysfunction, and promotes apoptosis [35].

High apoptotic cell death may play significant roles in I/R cellular injury. Emerging data indicate that both distinct types of cell death, necrosis and apoptosis may take place simultaneously in oxidative conditions like I/R injury [30]. Apoptosis plays a significant role in maintaining homeostasis in spermatogenesis, however, testicular I/R injury usually leads to wide-spread spermatogenic cell apoptosis, which can cause impaired testicular function and male infertility [36]

High levels of the initiator caspase- 8 and the executioner caspase- 3 were increased in testicular $\mathrm{I} / \mathrm{R}$ group in our study, but their levels were reduced by obestatin treatment in the treated I/R group. Caspase- 3 is an inactive zymogen in the cytoplasm and the convergence point of multiple apoptotic pathways. Its activation is an irreversible sign to induce cell apoptosis, leading to cell shrinkage, chromatin condensation and DNA degradation [37]

In addition, the present study revealed a significant increase in Bcl-2 associated $\mathrm{x}$ (Bax) protein expression with a significant decrease in $\mathrm{Bcl}-2$ expression (the second member of a range of proteins initially described in B-cell lymphoma; hence its nomenclature) in I/R testicular tissue, as measured by immunohistochemistry. The protective role of obestatin is also highlightened in the adjustment of $\mathrm{Bax}$ and $\mathrm{Bcl}-2$ expressions in obestatin treated group. Bcl-2 is a prosurvival multidomain protein that regulates apoptosis by preventing the release of proapoptogenic factors from the mitochondria (e.g., cytochrome c) and subsequent caspase activation [14]

Other studies also demonstrated that obestatin administration decreased cellular apoptosis in other 
degenerative diseases [38,39]. Zhang et al. [13] also showed that obestatin downregulated the expression of caspase- 3 and Bax and upregulated the expression of Bcl-2 and can rescue cardiomyocytes from I/R-induced injury. When the apoptosis signaling pathway is activated, Bax, a pro-apoptotic protein, is translocated to the mitochondria with cytochrome $\mathrm{C}$ release that leads to the initiation of the apoptotic cascade. This can be prevented by the anti-apoptotic protein $\mathrm{Bcl}-2$ via regulation of $\mathrm{Bax}$ [40] .

It has been demonstrated that the ratio of $\mathrm{Bcl}$ 2/Bax is crucial for normal spermatogenesis and determines whether apoptosis happens in cells exposed to damage [41]. Decrease in the Bcl-2/Bax ratio opens the mitochondrial permeability transition pore (MPTP), which further activates Caspase3 and contributes to spermatogenic cell apoptosis following I/R injury in the rat [2].

Conclusively, the present study demonstrated that obestatin has a benefit in reducing spermatogenic cell apoptosis and testicular damage that occurs after testicular ischemia reperfusion via attenuation of oxidative stress and inflammatory response and inhibition of the apoptosis pathway. Further clinical studies will be needed to evaluate its possible clinical applicability in patients with torsion.

\section{Acknowledgment:}

To Dr. Mona Mostafa Ahmed, Pathology Department, Faculty of Medicine, Zagazig University, for performing the histopatholgical and the immunohistochemical studies.

\section{References}

1- GHASEMNEJAD-BERENJI M., GHAZI-KHANSARI M., YAZDANI I., SAEEDI SARAVI S., NOBAKHT M., ABDOLLAHI A., MOHAJER ANSARI J., GHASEMNEJAD-BERENJI H., PASHAPOUR S. and DEHPOUR A.: Rapamycin protects testes against germ cell apoptosis and oxidative stress induced by testicular ischemiareperfusion. Iranian Journal of Basic Medical Sciences, 20 (8): 905-911, 2017.

2- NING J., LI W., CHENG F., RAO T., WEI- YU M., RUAN Y., YUAN R., ZHU S., ZHANG X., DU Y. and XIAO C.: The protective effects of GYY4137 on testicular torsion/detorsion injury in rats. Int. J. Clin. Exp. Med., 11 (4): 3387-3395, 2018.

3- CHI K., ZHANG W., WANG G., et al.: Comparison of intraperitoneal and intraepididymal quercetin for the prevention of testicular torsion/detorsion-induced injury. Urology, 99: 106-111, 2017.

4- KANTER M.: "Protective effects of melatonin on testicular torsion/detorsion-induced ischemia-reperfusion injury in rats", Experimental and Molecular Pathology, 89 (3): 314-320, 2010.
5- HENKEL R.: The impact of oxidants on sperm function. Andrologia, 37 (6): 205-206, 2005.

6- SHIH H.J., YEN J.C., CHIU A.W., CHOW Y.C., PAN W.H., WANG T.Y. and HUANG C.J.: FTY720 mitigates torsion/detorsion-induced testicular injury in rats. J. Surg. Res., 196: 325-331, 2015.

7- ALTAVILLA D., ROMEO C., SQUADRITO F., MARINI H., MORGIA G., ANTONUCCIO P., et al.: Molecular pathways involved in the early and late damage induced by testis ischemia: Evidence for a rational pharmacological modulation. Curr. Med. Chem., 19: 1219-1224, 2012.

8- AL-MAGHREBI M. and RENNO W.M.: Genistein alleviates testicular ischemia and reperfusion injury-induced spermatogenic damage and oxidative stress by suppressing abnormal testicular matrix metalloproteinase system via the Notch $2 /$ Jagged $1 /$ Hes-1 and caspase-8 pathways. J. Physiol. Pharmacol., 67 (1): 129-37, 2016.

9- YAPANOGLU T., OZKAYA F., YILMAZ A.H., et al.: Effect of etoricoxib on experimental oxidative testicular ischemia-reperfusion damage in rats induced with torsiondetorsion. Korean J. Physiol. Pharmacol., 21 (5): $457-$ 464, 2017.

10- LI J.B., ASAKAWA A., CHENG K., LI Y., CHAOLU H., TSAI M. and INUI A.: Biological effects of obestatin. Endocrine, 39 (3): 205-11, 2011.

11- KONARSKA K., CIESZKOWSKI J., WARZECHA Z., CERANOWICZ P., CHMURA A., KUR4IERZ-CABALA B, GAL'AZKA K, KOWALCZYK P., MISKIEWICZ A., KONTUREK T., PEDZIWIATR M. and DEMBIN'SKI A.: Treatment with Obestatin-A Ghrelin Gene-Encoded Peptide-Reduces the Severity of Experimental Colitis Evoked by Trinitrobenzene Sulfonic Acid. International Journal of Molecular Sciences, 19 (6): 1643, 2018.

12- EL-GOHARY O.A.: Obestatin improves hepatic injury induced by ischemia/reperfusion in rats: Role of nitric oxide General Physiology and Biophysics, 36 (1): 109115, 2017.

13- ZHANG Q., DONG X.W., XIA J.Y., XU K.Y. and XU Z.R.: Obestatin Plays Beneficial Role in Cardiomyocyte Injury Induced by Ischemia-Reperfusion In Vivo and In Vitro. Med. Sci. Monit., 23: 2127-2136, 2017.

14- RAMADAN B., SCHAALAN M. and MAHMOUD E.: Protective Effect of Taurine on Thiopurine-Induced Testicular Atrophy in Male Albino Rats. J. Steroids Horm Sci., 9 (1): 192, 2018.

15- TIETZ N.: Clinical Guide to Laboratory Tests, 3 rd Ed., W.B. Saunders Company, Philadelphia, 509-580, 1995.

16- OHKAWA H., OHISHI N. and YAGI K.: Assay for lipid peroxides in animals and tissue by thiobarbituric acid reaction. Anal. Biochem., 95: 351-358, 1979.

17- KAKKAR P., DAS B. and VISWANATHAN P.N.: A modified spectrophotometric assay of superoxide dismutase. Indian J. Biochem. Biophys., 21: 130-132, 1984.

18- LUCK H.: In: Methods in Enzymatic Analysis. Academic Press, 2: 885-890, 1974.

19- REDDY K.P., SUBHANI S.M., KHAN P.A. and KUMAR K.B.: Effect of light and benzyl adenine on dark-treated growing rice leaves, II changes in peroxidase activity. Plant Cell Physiol., 24: 987-994, 1995. 
20- RAGHAVENDRA V., TANGA F., RUTKOWSKI M.D. and DeLEO J.A.: Anti-hyperalgesic and morphine-sparing actions of propoentofylline following peripheral nerve injury in rats: Mechanistic implications of spinal glia and proinflammatory cytokines. Pain, 104 (3): 655-664, 2003.

21- ZHOU X.H., HAN Y.L., YANG H.M., et al.: Effects of SSTF on the expression of apoptosis-associated gene BCL2 and Bax by cardiomyocytes induced by $\mathrm{H} 2 \mathrm{O} 2$ Guangdong. Med. J., 28: 1590-1591, 2007.

22- WEI S.M., YAN Z.Z. and ZHOU J.: Beneficial effect of taurine on testicular ischemia-reperfusion injury in rats. Urology, 70 (6): 1237-42, 2007.

23- LIAN B., ONG C., CHIANG L., RAI R. and NAH S.: Factors predicting testicular atrophy after testicular salvage following torsion. European Journal of Pediatric Surgery, 26 (1): 17-21, 2016.

24- TAKHTFOOLADI M.A., SHAHZAMANI M., TAKHTFOOLADI H.A., MOAYER F. and ALLAHVERDI A.: Effects of light-emitting diode (LED) therapy on skeletal muscle ischemia reperfusion in rats. Lasers Med. Sci., 30 (1): 311-6, 2015.

25- AKONDI B.R., CHALLA S.R. and AKULA A.: Protective Effects of Rutin and Naringin in Testicular IschemiaReperfusion Induced Oxidative Stress in Rats. J. Reprod Infertil., 12 (3): 209-214, 2011.

26- BAYATLI F., AKKUS D., KILIC E., SARAYMEN R. and SONMEZ M.F.: The protective effects of grape seed extract on MDA, AOPP, apoptosis and eNOS expression in testicular torsion: An experimental study. World J. Urol., 31: 615-622, 2013.

27- YILDIZ H., DURMUS A., IMS A. and YAMAN M.: Protective effect of sildenafil citrate on contralateral testis injury after unilateral testicular torsion/detorsion. Clinics, 66 (1): 137-142, 2011.

28- AHMED A., LASHEEN N. and EL-ZAWAHRY K.: Ginkgo Biloba Ameliorates Subfertility Induced by Testicular Ischemia/Reperfusion Injury in Adult Wistar Rats: A Possible New Mitochondrial Mechanism. Oxidative Medicine and Cellular Longevity, Volume 2016, Article ID 6959274, 2016.

29- BOZLU M., COSKUN B., CAYAN S., et al.: Inhibition of poly (adenosine diphosphate-ribose) polymerase decreases long-term histologic damage in testicular ischemia reperfusion injury. Urology, 63 (4): 791-95, 2004.

30- TAATI M., MOGHADASI M., DEZFOULIAN O. and ASADIAN P.: Effects of Ghrelin on Testicular Ischemia/ Reperfusion-Induced Injury Acta. Med. Iran, 54 (1): 3238, 2016.
31- CZUBKOWSKI P., SOCHA P. and PAWLOWSKA J.: Current status of oxidative stress in pediatric liver transplantation. Pediatr. Transplant, 14: 169-177, (2010.

32- SEN L.S., KARAKOYUN B., YEG EN C., AKKIPRIK M., YÜKSEL M., ERCAN F., et al.: Treatment with either obestatin or ghrelin attenuates mesenteric ischemiareperfusion-induced oxidative injury of the ileum and the remote organ lung. Peptides, 71: 8-19, 2015.

33- TORNATORE L., THOTAKURA A.K., BENNETT J., MORETTI M. and FRANZOSO G.: The nuclear factor kappa B signaling pathway: Integrating metabolism with inflammation. Trends Cell Biol., 22: 557-566, 2012.

34- TAKHTFOOLADI M.A., MOAYER F. and TAKHTFOOLADI H.A.: Beneficial effect of pentoxifylline into the testis of rats in an experimental model of unilateral hindlimb ischemia/reperfusion injury. Int. Braz J. Urol., 41 (3): 576-83, 2015.

35- SHIMIZU S., SAITO M., KINOSHITA Y., SHOMORI K., SATOH I. and SATOH K.: Ischemic preconditioning and post-conditioning to decrease testicular torsiondetorsion injury. J. Urol., 182: 1637-1643, 2009.

36- LYSIAK J.J., NGUYEN Q.A., KIRBY J.L. and TURNER T.T.: Ischemia-reperfusion of the murine testis stimulates the expression of proinflammatory cytokines and activation of c jun N-terminal kinase in a pathway to E-selectin expression. Biol. Reprod, 69: 202-210, 2003.

37- ZHENG Y., ZHANG X., ZHOU J., CHENG F. and ZHOU B.: Effects on the ipsilateral testis during progression of experimental varicocele in rat. Med. Sci. Monit, 14: R122R126, 2008.

38- LI H.Q., WU Y.B., YIN C.S., CHEN L., ZHANG Q. and HU L.Q.: Obestatin attenuated doxorubicin-induced cardiomyopathy via enhancing long noncoding Mhrt RNA expression. Biomed Pharmacother, 81: 474-481, 2016.

39- LI W., CHANG M., QIU M., CHEN Y., ZHANG X., LI Q. and CUI C.: Exogenous obestatin decreases beta-cell apoptosis and alfa-cell proliferation in high fat diet and streptozotocin induced type 2 diabetic rats. Eur. J. Pharmacol., 16: 36-42, 2019.

40- KO M.L., CHEN C.F., PENG P.H. and PENG Y.H.: Simvastatin upregulates $\mathrm{Bcl}-2$ expression and protects retinal neurons from early ischemia/reperfusion injury in the rat retina. Exp. Eye Res., 93: 580-585, 2011.

41- LIANG H., YU F., TONG Z., YUAN B. and WANG C.: Effect of ischemia post-conditioning on skeletal muscle oxidative injury, mTOR, Bax, Bcl-2 proteins expression, and HIF- $1 \alpha / \beta$-actin mRNA, IL- $6 / p$-actin mRNA and caveolin-3/p-actin mRNA expression in ischemiareperfusion rabbits. Mol. Biol. Rep., 40: 507-514, 2008. 


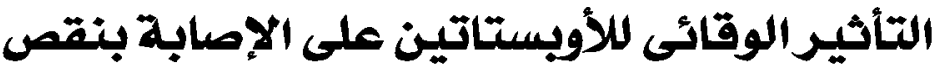

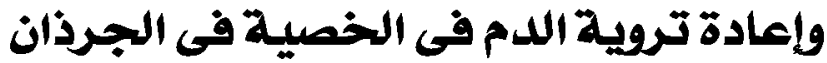

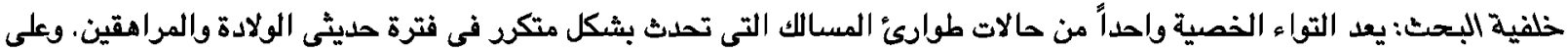

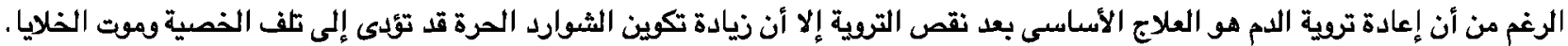

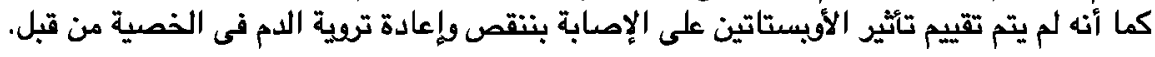

الهدف من البحث: تم تصميم هذه الدراسة لدراسة التأثير الوقائى المحتمل للأوبستاتين على الإصابة بنتقص وإعادة تروية الدم فى الخصية

$$
\text { في الجرذان. }
$$

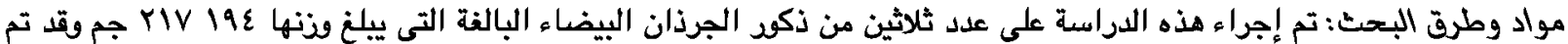

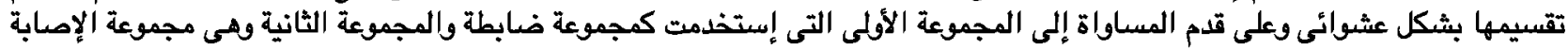

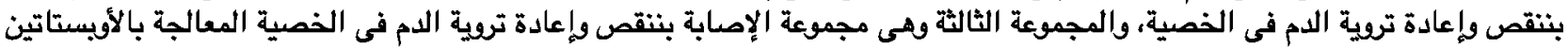

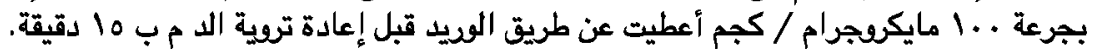

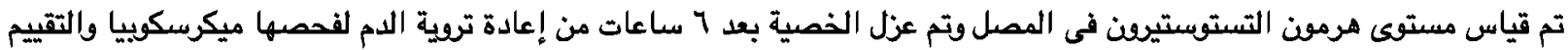

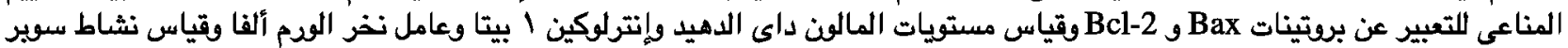

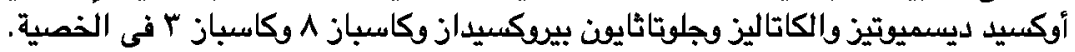

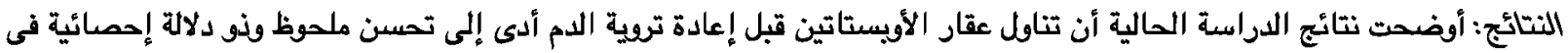

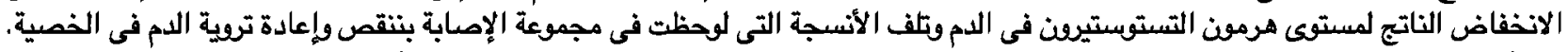

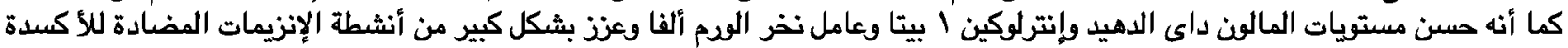

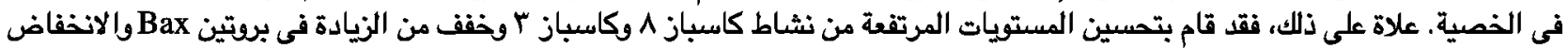

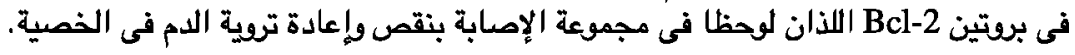

الأستتاج: الأوبستاتين له تأثير وقائى ضد الإصابة بنقص وإعادة تروية الدم فى الفصية والذى يمكن أن يعزى إلى خصائصه المضادة

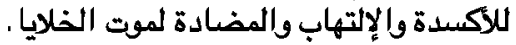

